\title{
EFFECTS OF DIETARY SORGHUM AND TRITICALE ON PERFORMANCE, CARCASS TRAITS AND MEAT PH IN BROILER CHICKENS
}

Anca Gheorghe*, Mihaela Hăbeanu, Margareta Olteanu, Raluca Paula Turcu, Cătălin Dragomi

National Research-Development Institute for Animal Biology and Nutrition (INCDBNA), 077015, Balotesti, Calea Bucuresti no. 1, Romania

\author{
${ }^{*}$ Corresponding author: \\ Phone: +40213512081 \\ Fax: +40213512080 \\ E-mail address: anca.gheorghe@ibna.ro
}

\begin{abstract}
The study was conducted to evaluate the effects of dietary partial corn replacement by white sorghum (WS) or triticale (T) on growth performance, carcass parameters and $\mathrm{pH}$ of meat in broilers. One-day-old unsexed Cobb 500 broilers $(n=600)$ were randomly assigned to 3 groups with 4 replicates per treatment. The broilers were fed with isocaloric and isonitrogenous corn-soybean meal control diets (C), corn-WS-soybean meal diets (WS) or corn-T-soybean meal diets (T) for 35 days. The WS or T partially replaced corn; proportions in diets were $275.4 \mathrm{~g} / \mathrm{kg}$ or $284.0 \mathrm{~g} / \mathrm{kg}$ (starter), $307.0 \mathrm{~g} / \mathrm{kg}$ or $308.2 \mathrm{~g} / \mathrm{kg}$ (grower) and $332.7 \mathrm{~g} / \mathrm{kg}$ or $335.0 \mathrm{~g} / \mathrm{kg}$ (finisher). Results showed that performance (body weight gain, feed intake and feed conversion ratio) or carcass traits (carcass yields, breast, leg, wings, liver and abdominal fat percentage) at $35 \mathrm{~d}$ were not affected by the inclusion of WS or T in diets. The $\mathrm{pH}$ values of breast (Pectoralis major) and thigh (Biceps femoris) muscle at 30 min and $24 \mathrm{~h}$ after slaughter were not influenced by the dietary treatments. In conclusion, partial corn replacement with white sorghum or triticale are suitable options for broiler chicken diet, with no adverse effects on growth performance, carcass characteristics or meat $\mathrm{pH}$, as important quality parameters.
\end{abstract}

Key words: broilers, white sorghum, triticale, carcass parameters, meat $\mathrm{pH}$

\section{INTRODUCTION}

The prices volatility and changes in the availability of corn, as major energy source used in poultry feeding, have increased interest in using other feed ingredients produced in large scale (Ravindran, 2013b). Sorghum (Sorghum bicolor L. Moench) and triticale (genus $X$ Triticosecale) are interesting energy ingredients for poultry and pig's diet due to its similar nutritional composition to corn or wheat (Leeson and Summers, 2005; Barneveld and Cooper, 2002). Furthermore, in the current context of climate change, it is expected that in the near future heat re- sistant crops such as sorghum or triticale are routinely utilized as food and feed resources for humans and animals (Selle et al., 2010; García et al., 2013). Previous study reported that the relatively high amount of antinutritional factors contained in old varieties of sorghum (condensed tannins) or triticale (soluble non-starch polysaccharides, NSP) grain can negatively influence the nutritive value of cereals (García et al., 2013; Selle et al., 2010; Korver et al., 2004). However, the use of new varieties of sorghum (low-tannin) or triticale in broiler diet as partial or total 
corn substitute have been associated with controversial results. Some studies showed a reduction in weight gain and feed intake and in-creased feed conversion in sorghum-based diets (Jacobs and Parsons, 2013; Robertson and Perez-Maldonado, 2010), or negative effects on performance and the intestinal mucosa (Torres et al., 2013), whereas others indicated similar performance (Fernandes et al., 2013; Rocha et al., 2008; Garcia et al., 2005). Several studies suggested that triticale may be incorporated in broiler diets with no major effect on the nutritive value of the diet or bird performance (Çiftci et al., 2003; Pourreza et al., 2007; Zarghi and Golian, 2009), while other findings (Korver et al., 2004; Santos et al., 2008) shown no effect on carcass parameters and quality of poultry meat.

This study was conducted to evaluate the effects of dietary partial corn replacement by white sorghum (WS) or triticale (T) on growth performance, carcass parameters and $\mathrm{pH}$ of meat in broilers.

\section{MATERIAL AND METHODS}

The experimental protocol was approved by the Animal Care Committee of the National Research-Development Institute for Animal Biology and Nutrition (Balotesti, Romania) and birds were treated in accordance with EU Directive 2010/63/EU (OJEU, 2010).

\section{Broilers, diets and sampling}

Six hundred one-day-old unsexed Cobb 500 broilers $(42.61 \pm 1.15 \mathrm{~g})$, housed in environmentally controlled conditions, were randomly assigned to 3 groups and kept in floor pens $(2.5 \mathrm{~m} \times 0.8 \mathrm{~m})$ with wood shavings. Each dietary treatment was replicated 4 times with 50 birds per replicate pen.

The birds were vaccinated according to the usual protocol against Newcastle disease and infectious bursal disease. Light schedule during the experimental period was $23 \mathrm{~h}$ of light and $1 \mathrm{~h}$ of dark.

Table 1.

Chemical composition and amino acid profile of cereals grain used in broiler diets

\begin{tabular}{lccc}
\hline Item (\%) & Corn & White Sorghum & Triticale \\
\hline Dry matter & 87.63 & 87.15 & 89.15 \\
Crude protein & 8.24 & 9.91 & 11.61 \\
Crude fat & 3.56 & 3.20 & 1.01 \\
Crude fiber & 1.96 & 2.56 & 3.83 \\
Ash & 2.33 & 1.14 & 1.84 \\
Nitrogen free extractive & 71.54 & 70.43 & 70.86 \\
Calcium & 0.03 & 0.02 & 0.03 \\
Phosphorus & 0.42 & 0.32 & 0.44 \\
Metabolizable energy (kcal/kg) & 3268 & 3207 & 2986 \\
\hline Amino acids (g/100g) & & & 0.451 \\
\hline Lysine & 0.212 & 0.266 & 0.250 \\
Methionine & 0.170 & 0.180 & 0.322 \\
Cysteine & 0.180 & 0.164 & 0.505 \\
Threonine & 0.269 & 0.457 & 0.776 \\
Arginine & 0.388 & 0.387 & 0.484 \\
Isoleucine & 0.278 & 0.389 & 0.816 \\
Leucine & 0.969 & 1.229 & 0.538 \\
Valine & 0.368 & 0.490 & 0.507 \\
Phenylalanine & 0.408 & 0.520 & 0.261 \\
Tyrosine & 0.305 & 0.376 & $\mathbf{4 . 9 1 0}$ \\
\hline Essential amino acids & $\mathbf{3 . 8 7 7}$ & $\mathbf{4 . 8 0 2}$ & 0.387 \\
\hline Glycine & 0.330 & 0.343 & 0.650 \\
Serine & 0.410 & 0.451 & 0.547 \\
Alanine & 0.629 & 0.708 & 0.780 \\
Aspartic acid & 0.580 & 0.662 & 3.291 \\
Glutamic acid & 1.554 & 1.895 & $\mathbf{5 . 6 5 5}$ \\
Non-essential amino acids & $\mathbf{3 . 5 0 2}$ & $\mathbf{4 . 0 5 9}$ & \\
\hline
\end{tabular}


Table 2.

Ingredient and nutrient composition of broiler diets for different growth phases

\begin{tabular}{|c|c|c|c|c|c|c|c|c|c|}
\hline \multirow[t]{2}{*}{ Ingredients (g/kg) } & \multicolumn{3}{|c|}{ Starter (1-10 d) } & \multicolumn{3}{|c|}{ Grower (11-22 d) } & \multicolumn{3}{|c|}{ Finisher (23-35 d) } \\
\hline & C & WS & $T$ & C & WS & $\mathbf{T}$ & C & WS & $T$ \\
\hline Corn & 560.0 & 275.4 & 284.0 & 600.0 & 307.0 & 308.2 & 657.6 & 332.7 & 335.0 \\
\hline White sorghum & - & 275.4 & - & - & 307.0 & - & - & 332.7 & - \\
\hline Triticale & - & . & 284.0 & - & 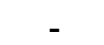 & 308.2 & 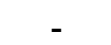 & . & 335.0 \\
\hline Soybean meal & 310.0 & 300.0 & 288.4 & 269.0 & 250.0 & 240.0 & 220.0 & 210.0 & 200.0 \\
\hline Corn gluten meal & 50.0 & 59.3 & 52.0 & 46.0 & 50.0 & 50.0 & 36.0 & 35.0 & 33.0 \\
\hline Sunflower oil & 28.0 & 37.8 & 39.8 & 35.0 & 36.0 & 44.0 & 40.0 & 43.0 & 50.0 \\
\hline $\begin{array}{l}\text { Monocalcium } \\
\text { phosphate }\end{array}$ & 18.2 & 17.9 & 18.2 & 17.0 & 16.2 & 16.6 & 15.0 & 14.6 & 14.8 \\
\hline Calcium carbonate & 14.7 & 14.8 & 14.7 & 13.9 & 14.0 & 13.9 & 12.7 & 12.8 & 12.7 \\
\hline Salt & 3.0 & 3.0 & 3.0 & 3.0 & 3.0 & 3.0 & 3.0 & 3.0 & 3.0 \\
\hline $\begin{array}{l}\text { Vitamin-mineral } \\
\text { premix }^{1}\end{array}$ & 10.0 & 10.0 & 10.0 & 10.0 & 10.0 & 10.0 & - & - & - \\
\hline $\begin{array}{l}\text { Vitamin-mineral } \\
\text { premix }^{2}\end{array}$ & - & - & - & - & - & - & 10.0 & 10.0 & 10.0 \\
\hline DL-methionine & 1.5 & 1.5 & 1.3 & 2.0 & 2.3 & 1.8 & 1.9 & 2.1 & 1.6 \\
\hline L-lysine $\mathrm{HCl}$ & 4.0 & 4.3 & 4.0 & 3.5 & 3.9 & 3.7 & 3.2 & 3.5 & 3.3 \\
\hline Choline $\mathrm{HCl}$ & 0.6 & 0.6 & 0.6 & 0.6 & 0.6 & 0.6 & 0.6 & 0.6 & 0.6 \\
\hline \multicolumn{10}{|c|}{ Calculated composition $(\mathrm{g} / \mathrm{kg})$} \\
\hline $\mathrm{ME}(\mathrm{MJ} / \mathrm{kg})^{3}$ & 12.61 & 12.62 & 12.63 & 12.97 & 12.98 & 12.95 & 13.31 & 13.32 & 13.29 \\
\hline Crude protein & 220 & 220 & 220 & 200 & 200 & 200 & 180 & 180 & 180 \\
\hline Lysine, total & 13.2 & 13.2 & 13.2 & 11.9 & 11.9 & 11.9 & 10.5 & 10.5 & 10.5 \\
\hline Lysine, digestible & 11.8 & 11.8 & 11.8 & 10.5 & 10.5 & 10.5 & 9.5 & 9.5 & 9.5 \\
\hline Met + cys, total & 9.8 & 9.8 & 9.8 & 8.9 & 8.9 & 8.9 & 8.2 & 8.2 & 8.2 \\
\hline Met + cys, digestible & 8.8 & 8.8 & 8.8 & 8.0 & 8.0 & 8.0 & 7.4 & 7.4 & 7.4 \\
\hline Calcium & 9.0 & 9.0 & 9.0 & 8.4 & 8.4 & 8.4 & 7.6 & 7.6 & 7.6 \\
\hline Available phosphorus & 4.5 & 4.5 & 4.5 & 4.2 & 4.2 & 4.2 & 3.9 & 3.9 & 3.9 \\
\hline Crude fiber & 35.4 & 34.3 & 39.2 & 33.1 & 33.7 & 36.9 & 30.4 & 31.6 & 35.3 \\
\hline Crude fat & 56.7 & 60.8 & 59.9 & 63.8 & 62.6 & 63.9 & 70.1 & 70.6 & 70.2 \\
\hline
\end{tabular}

C, control; WS, white sorghum; T, triticale

${ }^{1}$ Supplied per $\mathrm{kg}$ diet: retinyl acetate, $4.47 \mathrm{mg}$; cholecalciferol, $0.12 \mathrm{mg}$; DL- $\alpha$-tocopheryl acetate, $80 \mathrm{mg}$; menadione sodium bisulphite, $4 \mathrm{mg}$; thiamine mononitrate, $4 \mathrm{mg}$; riboflavin, $9 \mathrm{mg}$; pyridoxine- $\mathrm{HCl}, 4 \mathrm{mg}$; cyanocobalamin, $0.020 \mathrm{mg}$; Ca-panthotenate, $15 \mathrm{mg}$; niacin, $60 \mathrm{mg}$; folic acid, $2 \mathrm{mg}$; Mn, $100 \mathrm{mg}$; Zn, $100 \mathrm{mg}$; $\mathrm{Fe}, 40 \mathrm{mg}$; Cu, $15 \mathrm{mg}$; l, $1.0 \mathrm{mg}$; Se, $0.30 \mathrm{mg}$; Co, $0.25 \mathrm{mg}$, lasalocid sodium, $60 \mathrm{mg}$;

${ }^{2}$ Supplied per $\mathrm{kg}$ diet: retinyl acetate, $2.90 \mathrm{mg}$; cholecalciferol, $0.12 \mathrm{mg}$; DL- $\alpha$-tocopheryl acetate, $50 \mathrm{mg}$; menadione sodium bisulphite, $3 \mathrm{mg}$; thiamine mononitrate, $2 \mathrm{mg}$; riboflavin, $8 \mathrm{mg}$; pyridoxine- $\mathrm{HCl}, 3 \mathrm{mg}$; cyanocobalamin, $0.015 \mathrm{mg}$; Ca-panthotenate, $12 \mathrm{mg}$; niacin, $50 \mathrm{mg}$; folic acid, $1.5 \mathrm{mg}$; Mn, $100 \mathrm{mg}$; Zn, $100 \mathrm{mg}$; $\mathrm{Fe}, 40 \mathrm{mg}$; Cu, $15 \mathrm{mg}$; l, $1.0 \mathrm{mg}$; Se, $0.30 \mathrm{mg}$; Co, $0.25 \mathrm{mg}$;

${ }^{3}$ calculated using regression equations (NRC, 1994)

A 3-phase feeding regimen was used with the formulation of starter $(1-10 \mathrm{~d})$, grower $(11-22 \mathrm{~d})$ and finisher $(23-35 \mathrm{~d})$ diet. Broilers were fed with 3 diets: a control diet (C) based on corn-soybean meal, a corn-white sorghum-soybean meal diet (WS) and a corn-triticale-soybean meal diet (T) for $35 \mathrm{~d}$. The WS and T that partially $(50 \%)$ replace corn in the experimental diets were obtained from local cultivars. The analysed chemical composition and concentration of amino acids of white sorghum and triticale compared with corn are presented in Table 1. The diets were isocaloric and isonitrogenous, formu- lated to meet similar content of digestible sulphur amino acids, lysine, calcium and available phosphorus (Cobb-Vantress, 2015). The ingredients and calculated composition of the diets are shown in Table 2. Feed and water were provided ad libitum throughout the experimental period. Feed was withdrawn during $12 \mathrm{~h}$ before slaughter.

Evaluated performance parameters were body weight (BW) and feed intake $(\mathrm{FI})$ for grower phases and overall period, from which body weight gain (BWG) and feed conversion ratio (FCR) were calculated. Mortality was recorded daily. 
At $35 \mathrm{~d}$ of age, six broilers per replicate were randomly selected for carcass evaluation and muscle $\mathrm{pH}$ measurements. The broilers were weighed, killed by cervical dislocation, bleed and manually eviscerated. The weight of the whole carcass was determined. Carcass yield, breast and legs (with skin and bone), wings, liver and abdominal fat percentage were calculated based on final live body weight (BW).

\section{Chemical analysis}

Standardized methods according to EU Regulation 152/2009 (OJEU, 2009) were used to determine the chemical composition of feed ingredients and diet samples: dry matter (gravimetric method; SR ISO 6496:2001), crude protein (Kjeldahl method; SR EN ISO 5983-2:2009), crude fat (an improved version of classical method by continuous extraction in solvent; SR ISO 6492:2001), crude fibre (FibertecTecator method; SR EN ISO 6865:2002), crude ash (gravimetric method; SR EN ISO 2171:2010).

Amino acid content of ingredients was determined by reversed phase chromategraphy RP-HPLC) method, using high performance liquid chromatograph, Finnigan Surveyor Plus HPLC (Thermo-Electron Corporation, Waltham, USA).

\section{Muscle pH}

A portable HACCP compliant $\mathrm{pH}$ meter for meat (HI 99163, Hanna Instruments, EU) with a pH electrode (FC 232D, Hanna Instruments, EU) and stainless-steel penetration blade (FC 099, Hanna Instruments, $\mathrm{EU})$ was used to measure muscle $\mathrm{pH}$ at $30 \mathrm{~min}$ and $24 \mathrm{~h}$ after slaughter. The $\mathrm{pH}$ meter electrode was introduced directly into the left breast (Pectoralis major) and thigh (Biceps femoris) muscle at a depth of $2.0 \mathrm{~cm}$ below the surface.

\section{Statistical analysis}

The data obtained were analysed using the GLM procedure (SPSS, 2011). Oneway analysis of variance (ANOVA) with the Tukey's comparison test was used to evaluate statistical significance of differences between dietary treatments. The results are given as means and standard error of the mean (SEM). Differences were considered significant at $\mathrm{P} \leq 0.05$.

\section{RESULTS AND DISCUSSION}

\section{Growth performance}

The average body weight gain (BWG), feed intake (FI) and FCR (feed conversion ratio), during respective growth phases and overall period are shown in Table 3.

Table 3.

Effects of dietary treatments on growth performance of broilers ${ }^{1}$

\begin{tabular}{|c|c|c|c|c|c|}
\hline \multirow[t]{2}{*}{ Item } & \multicolumn{3}{|c|}{ Dietary treatments } & \multirow[t]{2}{*}{ SEM } & \multirow[t]{2}{*}{ P-Value } \\
\hline & C & WS & $T$ & & \\
\hline Starter $(1-10 d)$ & & & & & \\
\hline BWG (g/bird) & 220.05 & 211.47 & 209.54 & 3.02 & 0.174 \\
\hline FI (g/bird) & 274.45 & 265.95 & 264.18 & 1.99 & 0.254 \\
\hline $\begin{array}{l}\text { FCR (g feed:g gain) } \\
\text { Grower }(11-22 d)\end{array}$ & 1.24 & 1.25 & 1.27 & 0.22 & 0.129 \\
\hline BWG (g/bird) & 677.18 & 684.35 & 672.67 & 5.33 & 0.109 \\
\hline $\mathrm{FI}$ (g/bird) & 1020.41 & 1030.67 & 1034.44 & 4.21 & 0.780 \\
\hline $\begin{array}{l}\text { FCR (g feed:g gain) } \\
\text { Finisher }(23-35 d)\end{array}$ & 1.50 & 1.51 & 1.54 & 0.05 & 0.492 \\
\hline BWG (g/bird) & 998.63 & 987.58 & 983.79 & 2.31 & 0.178 \\
\hline FI (g/bird) & 2027.05 & 2036.28 & 2041.45 & 8.05 & 0.890 \\
\hline $\begin{array}{l}\text { FCR (g feed:g gain) } \\
\text { Overall period }(1-35 d)\end{array}$ & 2.03 & 2.06 & 2.07 & 0.02 & 0.930 \\
\hline BWG (g/bird) & 1895.86 & 1883.40 & 1866.00 & 7.47 & 0.272 \\
\hline $\mathrm{FI}$ (g/bird) & 3321.91 & 3332.81 & 3340.07 & 6.26 & 0.930 \\
\hline FCR (g feed:g gain) & 1.75 & 1.77 & 1.79 & 0.03 & 0.092 \\
\hline
\end{tabular}

${ }^{1}$ Means of 50 broilers per replicate;

$C$, control diet; WS, white sorghum diet; T, triticale diet; SEM-standard error of mean;

BWG, body weight gain; Fl, feed intake; FCR, feed conversion ratio;

"Means within rows do not differ significantly $(P>0.05)$ 
Table 4.

Effects of dietary treatments on carcass characteristics of broilers at $35 d^{1}$

\begin{tabular}{|c|c|c|c|c|c|}
\hline \multirow[t]{2}{*}{ Item \% } & \multicolumn{3}{|c|}{ Dietary treatments } & \multirow[t]{2}{*}{ SEM } & \multirow[t]{2}{*}{ P-Value } \\
\hline & C & WS & $T$ & & \\
\hline Carcass yield & 70.71 & 70.40 & 70.20 & 0.20 & 0.602 \\
\hline Breast & 25.10 & 24.39 & 23.25 & 0.58 & 0.459 \\
\hline Legs & 19.61 & 19.11 & 19.32 & 0.17 & 0.548 \\
\hline Wings & 7.65 & 7.79 & 8.10 & 0.11 & 0.256 \\
\hline Liver & 2.12 & 2.10 & 2.06 & 0.04 & 0.830 \\
\hline Abdominal fat & 1.37 & 1.27 & 1.26 & 0.03 & 0.302 \\
\hline
\end{tabular}

${ }^{1}$ Means of 6 broilers per replicate;

$C$, control diet; WS, white sorghum diet; $T$, triticale diet; SEM-standard error of mean;

Means within rows do not differ significantly $(P>0.05)$

Table 5.

Effects of dietary treatments on muscle $\mathrm{pH}$ of broilers at $35 \mathrm{~d}^{1}$

\begin{tabular}{|c|c|c|c|c|c|}
\hline \multirow[t]{2}{*}{ Item } & \multicolumn{3}{|c|}{ Dietary treatments } & \multirow[t]{2}{*}{ SEM } & \multirow[t]{2}{*}{ P-Value } \\
\hline & C & WS & $\mathbf{T}$ & & \\
\hline \multicolumn{6}{|l|}{ Breast (Pectoralis major) } \\
\hline $\mathrm{pH}_{30 \text { min. }}$ & 6.067 & 6.025 & 6.037 & 0.011 & 0.263 \\
\hline $\begin{array}{l}\mathrm{pH}_{24 \mathrm{~h}} \\
\text { Thigh (Biceps fermoris) }\end{array}$ & 5.913 & 5.857 & 5.863 & 0.014 & 0.437 \\
\hline $\mathrm{pH}_{30 \text { min. }}$ & 6.132 & 6.157 & 6.166 & 0.012 & 0.783 \\
\hline $\mathrm{pH}_{24 \mathrm{~h}}$ & 5.948 & 5.959 & 5.968 & 0.010 & 0.879 \\
\hline
\end{tabular}

${ }^{1}$ Means of 6 broilers per replicate; Means within rows do not differ significantly $(P>0.05)$;

$\mathrm{pH} 30 \mathrm{~min}, \mathrm{pH} 24 \mathrm{~h}-\mathrm{pH}$ values measured at $30 \mathrm{~min}$ and $24 \mathrm{~h}$ post mortem;

$C$, control diet; WS, white sorghum diet; $T$, triticale diet; SEM-standard error of mean

There were no significant differences in BWG, FI and FCR ( $>>0.05)$ among the dietary treatments during the experimental period, suggesting that partial corn replacement with sorghum or triticale did not negatively affect broilers performance. Mortality percentage was low and did not differ significantly $(P>0.05)$ among the dietary treatments (data not shown).

The results of our study are consistent with previous reports of others (Garcia et al., 2013; Torres et al., 2013; Stringhini et al., 2009; Rocha et al., 2008; Santos et al., 2006) who did not find any differences in feed intake, weight gain or feed conversion when evaluating the growth performance of broilers fed sorghum as partial corn replacement in diets. Zarghi and Golian, (2009) also, revealed that 50\% corn replacement with triticale had no negative effect on broiler growth performance. Mierlita, (2008) suggested that replacing $30 \%$ of the corn with triticale did not significantly influence performance and carcass traits, while $60 \%$ substitution ratio affected weight gain, feed intake, FCR, carcass parameters and carcass fat quality. Conversely, Baser and Yetisir (2014) showed that partial or total replacement of corn with triticale in diet impaired broilers growth performance and carcass parameters.

\section{Carcass characteristics}

Carcass yield and carcass cut-up parts yield of broiler chickens at $35 \mathrm{~d}$ (Table 4) were not significantly affected by the dietary treatments $(P>0.05)$. In previous studies related with dietary partial corn replacement with sorghum (Torres et al., 2013; Garcia et al., 2013; Stringhini et al. 2009; Kumar et al. 2005) or triticale (Zarghi and Golian, 2009) no negative effect on carcass yield and/or cut-up parts was observed.

\section{Muscle pH}

An important factor in chicken meat quality evaluation is $\mathrm{pH}$. Functional properties of meat dependent on glycolytic reactions which occur during rigor mortis, affecting meat $\mathrm{pH}$ directly. Also, the fasting period is related to meat $\mathrm{pH}$ and affects the incidence of pale soft exudative (PSE) meat in broiler chickens (Komiyama et al., 2008). As shown in Table 5 the $\mathrm{pH}$ values of breast (Pectoralis major) and thigh (Biceps femoris) muscle at 30 min and $24 \mathrm{~h}$ after slaughter were not influenced by the treat- 
ments. Breast and thigh muscle $\mathrm{pH}$ was not affected $(P>0.05)$ by the partial corn replacement by white sorghum or triticale in the diet. The $\mathrm{pH}$ values obtained were in the normal limits for this parameter (5.75.96 for breast and 6.0-6.2 for thigh meat; Fletcher et al., (2000). Similarly, Garcia et al., (2013) reported that partial substitution of corn by sorghum in the diet did not influence breast and thigh meat $\mathrm{pH}$ values.

\section{CONCLUSIONS}

In conclusion, partial corn replacement with white sorghum or triticale are suitable options for broiler chicken diets, with no adverse effects on growth performance, carcass characteristics or meat $\mathrm{pH}$, as important quality parameters.

\section{ACKNOWLEDGEMENTS}

This work was supported by funds from the Romanian Ministry of Research and Innovation through Nucleus Program, Project No. 16410105 "Evaluation of the nutritional potential of local feed resources in broilers feeding".

\section{REFERENCES}

1. Barneveld, R.J., Cooper, K.V. (2002). Nutritional quality of triticale for pigs and poultry. $5^{\text {th }}$ International Triticale Symposium, Radzików, Poland, Proceedings, 1, pp. 277-282.

2. Başer, E., Ramazan, Y. (2014). Effects of triticale replacement without any enzymes on carcass performance of broiler chickens. Turkish Journal of Agricultural and Natural Sciences, Special Issue: 2, 1468-1474.

3. Bryden, W.L., Selle, P.H., Cadogan, D.J., Li, X., Muller, N.D., Jordan, D.R., Gidley, M.J., Hamilton, W.D. (2009). A Review of the Nutritive Value of Sorghum for Broilers, Rural Industries Research and Development Corporation (RIRDC) Publication No. 09/077, Barton, ACT.

4. Çiftci, İ., Yenice, E., Eleroglu H. (2003). Use of triticale alone and in combination with wheat or maize: Effects of diet type and enzyme supplementation on hen performance, egg quality, organ weights, intestinal viscosity and digestive system characteristics. Animal Feed Science and Technology, 105, 149-161.

5. Cobb-Vantress (2015). Coob 500 Broiler Performance and Nutrition Supplement (www.cobb-vantress.com).

6. Commission Regulation (EU) No. 152 (2009). Official Journal of the European Union, L 54.

7. Directive (EU) No. 63 (2010). Official Journal of the European Union, L 276, 33-79.

8. Fletcher D.L., Giao M., Smith D.P. (2000). The relationship of raw broiler breast meat color and
$\mathrm{pH}$ to cooked meat color and $\mathrm{pH}$. Poultry Science, 79, 784-788.

9. Garcia, R.G., Mendes, A.A., Almeida, Paz, I.C.L., Komiyama, C.M., Caldara, F.R., Nääs, I.A., Mariano, W.S. (2013). Implications of the use of sorghum in broiler production. Revista Brasileira de Cięncia Avícola, 15 (3), 169-286.

10. Garcia, R.G., Mendes, A.A., Costa, C, Paz, ICLA, Takahashi, S.E., Pelícia, K.P., Komiyama, C.M., Quinteiro, R.R. (2005). Desempenho e qualidade da carne de frangos de corte alimentados com diferentes níveis de sorgo em substituição ao milho. Arquivo Brasileiro de Medicina Veterinária e Zootecnia, 57, 634-643.

11. Komiyama C.M., Mendes A.A., Takahashi S.E., Moreira J., Garcia R.G. (2008). Chicken meat quality as a function of fasting period and water spray. Brazilian Journal of Poultry Science, 10, 179-183.

12. Korver, D.R., Zuidhof, M.J., Lawesk R. (2004). Performance characteristics and economic comparison of broiler chickens fed wheat- and triticale-based diets. Poultry Science, 83, 716725.

13. Kumar, V., Elangovan, A.V., Mandal, A.B. (2005). Utilization of reconstituted high-tannin sorghum in the diets of broiler chickens. AsianAustralasian Journal of Animal Science, 18, 538-544.

14. Leeson, S., Summers, J.D. (2005). Commercial Poultry Nutrition, Nottingham University Press, Nottingham, England, p. 395.

15. Jacobs, C., Parsons, C.M. (2013). The effects of coarse ground corn, whole sorghum, and a prebiotic on growth performance, nutrient digestibility, and cecal microbial populations in broilers fed diets with and without corn distillers dried grains with solubles. Poultry Science, 92, 2347-2357.

16. Mierlită, D. (2008). Triticale use in broiler chicken diets and its effect on production and economic efficiency fattening. Bulletin UASVM Animal Science and Biotechnologies, 65 (1-2), 66-71.

17. NRC (1994). Nutrient Requirements of Poultry, $9^{\text {th }}$ Ed., National Academy Press, Washington DC, USA.

18. Pourreza, A.H., Samie, A.H., Rowghani, E. (2007). Effect of supplemental enzyme on nutrient digestibility and performance of broiler chicks fed on diets containing triticale. International Journal of Poultry Science, 6, 115-117.

19. Ravindran, V. (2013). Alternative feedstuffs for use in poultry feed formulations. In Poultry development review (ed.). FAO, pp. 72-75 (www.fao.org/publications).

20. Robertson S.K., Perez-Maldonado R.A. (2010). Nutritional characteristics of sorghums from QSL and MSW. Zootecnica International, 32, 38-43.

21. Rocha, V.R.R.A., Junior, W.M.D., Rabello, C.B.V., Ramalho, R.P., Ludke, M.C.M.M., Silva, E.C. (2008). Substituição total do milho por sorgo e óleo de abatedouro avícola em dietas para frangos de corte. Revista Brasileira de Zootecnia, 37, 95- 102. 
22. Santos, M.S.V, Espíndola, G.B, Fuentes, M.F.F, Freitas, E.R, Carvalho, L.E. (2006). Utilizaçăo de complexo enzimático em dietas ŕ base de sorgo-soja para frangos de corte. Revista Brasileira de Zootecnia, 35, 811-817.

23. Santos, F.B.O., Sheldon, B.W., Santos, A.A. Jr., Ferket, P.R. (2008). Influence of housing system, grain type, and particle size on Salmonella colonization and shedding of broilers fed triticale or corn-soybean meal diets. Poultry Science, 87, 405-420.

24. Selle, P.H, Cadogan, D.J., Li, X., Bryden, W.L. (2010). Implications of sorghum in broiler chicken nutrition. Animal Feed Science and Technology, 156, 57-74.

25. Stringhini, J.B, Arantes, U.M., Laboissičre, M., Cunha, M.I.R., Pedroso, A.A., Leandro N.S.M.
(2009). Desempenho de frangos de corte consumindo raçőes contend sorgo e gérmen integral de milho. Revista Brasileira de Zootecnia, 38, 2435-2441.

26. SPSS (2011). Statistics, version 20.0. IBM SPSS Inc., USA.

27. Torres, K.A.A, Pizauro, J.M. Jr, Soares, C.P, Silva, T.G.A, Nogueira, W.C.L., Campos, D.M.B., Furlan, R.L., Macari, M. (2013). Effects of corn replacement by sorghum in broiler diets on performance and intestinal mucosa integrity. Poultry Science, 92, 1564-1571.

28. Zarghi, H., Golian, A. (2009). Effect of triticale replacement and enzyme supplementation on performance and blood chemistry of broiler chickens. Journal of Animal Veterinary Advances, $8(7), 1316-1321$.

\title{
ЕФЕКАТ ДОДАТКА СИРКА И ТРИТИКАЛЕА У ИСХРАНИ БРОЛЛЕРА НА ПРОИЗВОДНЕ ПЕРФОРМАНСЕ, ПОКАЗАТЕЉЕ КВАЛИТЕТА ТРУПА И РН ВРЕДНОСТ МЕСА
}

\author{
Анка Георге*, Михаела Хабеану, Маргарета Олтеану, Ралука Паула Турку, Каталин Драгомир
}

Национални истраживачки развојни институт за биологију и исхрану животиња (INCDBNA), Калеа Букурешти бр. 1, Балотешти, 077015, Румунија

Сажетак: Приказана студија изведена је како би се испитао ефекат делимичне замене кукуруза белим сирком (БС) или тритикалеом (Т) у исхрани бројлера, на производне перформансе, показатеље квалитета трупа и pH вредност меса. Једнодневни Cobb 500 бројлерски пилићи истог пола (600 комада) су насумично подељени у три групе, са по четири понављања по третману. Бројлери су храњени изо-калоричним и изо-азотним оброцима 35 дана: контролни оброци на бази кукуруза и сојине сачме (К), кукуруз-БС-сојина сачма оброци (БС), или кукуруз-Т-сојина сачма оброци (Т). Кукуруз је био парцијално замењен са БС или Т на следећи начин: односи у оброцима су били $275,4 \mathrm{~g} / \mathrm{kg}$ или $284,0 \mathrm{~g} / \mathrm{kg}$ (стартер), $307,0 \mathrm{~g} / \mathrm{kg}$ или $308,2 \mathrm{~g} / \mathrm{kg}$ (гровер) и $332,7 \mathrm{~g} / \mathrm{kg}$ или $335,0 \mathrm{~g} / \mathrm{kg}$ финишер, редом. Резултати су показали да производне перформансе (принос масе, унос хране и конверзија хране), као и показатељи квалитета трупа (принос масе трупа и процентуални удео груди, ногу, крила, јетре и абдоминалне масноће) нису зависили од уноса БС или Т у исхрану. Начин исхране није утицао ни на pH вредност меса груди (Pectoralis major) и карабатака (Biceps femoris) мерено после 30 минута и 24 сата након клања. Може се извести закључак да је парцијална замена кукуруза белим сирком или тритикалеом у исхрани бројлерских пилића адекватна и да нема негативне ефекте на производне перформансе, карактеристике трупа и $\mathrm{pH}$ вредност меса, као важне показатеље квалитета.

Кључне речи: бројлери, бели сирак, тритикале, параметри трупа, $\mathrm{pH}$ вредност меса

Received: 18 October 2017

Accepted: 22 November 2017 